\title{
Protecting Young Women from HIV/AIDS: The Case Against Child and Adolescent Marriage
}

\begin{abstract}
CONTEXT: In most developing countries, the majority of sexually active female adolescents are married. Although married adolescents are often assumed to be at low risk for HIV infection, little is known about the actual HIV risks these adolescents face or about ways to minimize these risks.
\end{abstract}

METHODS: Demographic and Health Survey data from 29 countries in Africa and Latin America were used to examine the frequency of factors that may increase HIV risk in married women aged 15-19.

RESULTS: Several behavioral and social factors may increase the vulnerability of married female adolescents to HIV infection. First, these young women engage in frequent unprotected sex: In most countries, more than $80 \%$ of adolescents who had had unprotected sex during the previous week were married. Second, women who marry young tend to have much older husbands (mean age difference, 5-14 years) and, in polygamous societies, are frequently junior wives, factors that may increase the probability that their husbands are infected and weaken their bargaining power within the marriage. Third, married adolescents have relatively little access to educational and media sources of information about HIV. Finally, the most common AIDS prevention strategies (abstinence, condom use) are not realistic options for many married adolescents.

CONCLUSION: New policies and interventions, tailored to the sexual and behavioral profiles of women in each country, are needed to address the vulnerabilities of adolescent wives. In some countries, delaying age at marriage may be an important strategy; in others, making intercourse within marriage safer may be more valuable.

International Family Planning Perspectives, 2006, 32(2):79-88
By Shelley Clark, Judith Bruce and

Annie Dude

At the time this article was written, Shelley Clark was assistant professor, Harris Graduate School of Public Policy, University of Chicago, Chicago, IL, USA. Judith Bruce is director of family, gender and development, Population Council, New York. Annie Dude is a doctoral student, Harris Graduate School of Public Policy.
During the past decade, two demographic trends in developing countries have received considerable attention: the unprecedented size of the current cohort of adolescents and the steadily increasing percentage of women infected with HIV. ${ }^{1}$ Much of the acceleration in the spread of HIV among women has occurred among adolescents. In some parts of the world, notably Sub-Saharan Africa, the prevalence of HIV among women aged 15-24 is two to eight times that among men in the same age-group. ${ }^{2}$ In response, policymakers have increasingly sought to address the reproductive and sexual health needs of adolescents, particularly female adolescents. Most of the resulting policies and programs, however, pay surprisingly little attention to the large proportion of female adolescents who are married.

Child and adolescent marriage remains common in many parts of the developing world. ${ }^{3}$ Almost a third of the more than 330 million girls and young women aged 10-19 who currently live in developing countries (excluding China) were or will be married by their 18 th birthday. ${ }^{4}$ In the majority of these countries, most of the sexual intercourse involving female adolescents occurs within marriage. ${ }^{5}$

Although the risk of HIV transmission between spouses is extremely low under certain conditions-specifically, when both partners are uninfected at the time of marriage and subsequently engage in sexual activity exclusively with each other-these conditions are often not met. When they are violated, as is frequently the case for women who marry at a very young age, sexual intercourse with a spouse is risky. Indeed, in some settings, married adolescents have higher rates of HIV infection than their sexually active unmarried peers. ${ }^{6}$ Thus, married female adolescents not only represent a sizable fraction of adolescents at risk of contracting HIV via heterosexual intercourse, but also a group with high rates of HIV infection.

Nonetheless, many policymakers and parents, and even young women themselves, continue to perceive marriage as a haven from the risk of HIV infection. Parents in Malawi, for example, encourage their daughters to marry early to protect them from HIV. ${ }^{7}$ Moreover, many international and national AIDS prevention messages encourage abstinence until marriage; these messages imply that sex within marriage is not only more socially sanctioned than premarital sex, but also somehow provides complete protection against HIV.

In this article, we present evidence from a series of international surveys about four important aspects of young women's lives. These data call into question the often deeply ingrained belief that marriage protects young women from HIV. First, for many adolescents-particularly the youngest brides-marriage greatly increases their potential exposure to the virus, because marriage results in a transition from virginity to frequent unprotected sex. Even among adolescents who are already sexually active, marriage generally leads to 


\begin{tabular}{|c|c|c|c|c|}
\hline \multirow[t]{2}{*}{ Country } & \multirow{2}{*}{$\begin{array}{l}\text { Year of } \\
\text { survey }\end{array}$} & \multicolumn{3}{|l|}{$\%$ married } \\
\hline & & By age 15 & By age 18 & By age 20 \\
\hline \multicolumn{5}{|c|}{ South and East Africa } \\
\hline Ethiopia & 2000 & 19.1 & 49.1 & 64.7 \\
\hline Kenya & 2003 & 5.6 & 37.8 & 70.8 \\
\hline Malawi & 2000 & 10.2 & 46.9 & 72.9 \\
\hline Mozambique & 2003 & 18.4 & 55.9 & 74.9 \\
\hline Namibia & 2000 & 8.3 & 34.3 & 58.3 \\
\hline Rwanda & 2000 & 2.1 & 19.5 & 41.6 \\
\hline South Africa & 1998 & 1.1 & 7.9 & 14.2 \\
\hline Tanzania & 2003 & 4.3 & 22.1 & 39.2 \\
\hline Uganda & $2001-2002$ & 17.5 & 62.9 & 87.5 \\
\hline Zambia & 2001-2002 & 7.8 & 42.1 & 63.3 \\
\hline Zimbabwe & 1999 & 4.6 & 28.7 & 52.9 \\
\hline \multicolumn{5}{|l|}{ West Africa } \\
\hline Benin & 2001 & 7.5 & 36.7 & 58.5 \\
\hline Burkina Faso & 2003 & 6.2 & 62.2 & 90.2 \\
\hline Cameroon & 2004 & 16.5 & 47.2 & 64.0 \\
\hline Côte d'Ivoire & 1998-1999 & 14.3 & 49.7 & 76.2 \\
\hline Gabon & 2000 & 10.8 & 33.6 & 48.9 \\
\hline Ghana & 2003 & 10.4 & 48.0 & 79.8 \\
\hline Guinea & 1999 & 27.5 & 64.5 & 78.8 \\
\hline Mali & 2001 & 24.5 & 65.4 & 80.9 \\
\hline Niger & 1998 & 39.5 & 86.6 & 95.9 \\
\hline Nigeria & 2003 & 30.0 & 67.6 & 86.8 \\
\hline Togo & 1998 & 14.3 & 49.7 & 77.6 \\
\hline \multicolumn{5}{|c|}{ Latin America/Caribbean } \\
\hline Brazil & 1996 & 4.4 & 23.7 & 38.8 \\
\hline Colombia & 2000 & 4.1 & 21.4 & 37.1 \\
\hline Dom. Republic & 2002 & 9.6 & 31.0 & 45.4 \\
\hline Guatemala & 1998-1999 & 9.3 & 34.3 & 55.4 \\
\hline Haiti & 2000 & 5.3 & 24.1 & 43.0 \\
\hline Nicaragua & 2001 & 16.0 & 50.3 & 65.6 \\
\hline Peru & 2003 & 2.6 & 17.0 & 27.9 \\
\hline
\end{tabular}

a dramatic rise in the frequency of unprotected intercourse, especially when pregnancy is desired. Second, the partners of married female adolescents are typically older-and, by virtue of their age, more likely to be HIV-positive-than the boyfriends of unmarried female adolescents. In addition, in polygamous societies, child and adolescent brides are more likely than older brides to be second or third wives. Third, women who marry as adolescents receive less formal education and have less exposure to the media than their unmarried peers, greatly reducing their opportunities to receive information about HIV/AIDS via these channels and potentially undermining their ability to negotiate safer sexual practices. Fourth, in addition to being mounted in venues that are relatively inaccessible to married adolescents, HIV

*We constructed two additional variables using DHS questions on pregnancy intentions, timing of last sex and condom use. First, we coded young women as having had "unprotected sex within the last week" if they reported having had sexual intercourse within the past seven days and if their partner at the time did not use a condom during last intercourse. Second, we classified women as "actively seeking pregnancy" if they reported wanting to become pregnant within the next two years.

tIn the DHS III series, women were first asked a series of questions about current partners and sexual activities. Respondents with a history of sexual activity were then asked, "How old were you when you first had sexual intercourse?" In the DHS+ series, all women were asked "How old were you when you first had sexual intercourse (if ever)?" Questions about current sexual behaviors and partners were asked only if a respondent reported that she had already initiated sexual activity. outreach programs are often geared toward unmarried adolescents and other groups that are considered to be high-risk. These programs often promote protection strategies that are either inappropriate for married adolescents or difficult for them to implement, such as using condoms or abstaining from sexual activity.

\section{DATA AND METHODS}

The data in our analysis come from Demographic and Health Surveys (DHS) conducted between 1996 and 2004 in 22 African countries and seven countries in Latin America and the Caribbean. In each country, a nationally representative sample of women aged 15-49 was surveyed. The majority of surveys used the DHS+ version of the questionnaire, although an older version (DHS III) was used in five countries (South Africa, Niger, Togo, Côte d'Ivoire and Brazil). These instruments included identical questions about respondents' demographic and socioeconomic characteristics, marital status, recent sexual activity, pregnancy intentions and current contraceptive methods. * There were subtle differences between the DHS III and DHS+ in the questions regarding age at first sex, ${ }^{\dagger}$ but these differences have little effect on reports of sexual activity. ${ }^{8}$

Our analyses focus on the sexual and social dynamics of 15-19-year-old adolescent females. The majority of our analyses rely on current status reports from married and sexually active unmarried young women in this age range; in a few analyses, we used data from an older cohort of women to avoid censoring younger adolescents who were not yet married or had not yet completed their schooling. All data are weighted using the probability sampling weights provided by DHS.

\section{RESULTS \\ Rates of Early Marriage and HIV Status}

Marriage before age 20 is common in Sub-Saharan Africa (Table 1). In all of the African countries we studied, with the notable exception of South Africa, at least four of every 10 women marry before reaching their 20th birthday. In Latin America and the Caribbean, between one-quarter and twothirds of young women marry during their teenage years. Some of the national data mask considerable local variation; the proportions of young women married by age 18 in the Amhara region of Ethiopia (80\%; data not shown) and in Kayes, Mali (83\%), are substantially higher than the national rates for those countries (49\% and 65\%, respectively).

The HIV status of most adolescents in Africa and Latin America is unknown, although a handful of studies suggest that the prevalence of HIV among married adolescent females is relatively high. In some urban areas of Kenya and Zambia, for example, the prevalence of HIV infection among married adolescent females is 33\% and 27\%, respectively, whereas the prevalence among sexually active unmarried females in these areas is 22\% and $17 \% .{ }^{9}$ Nationally representative samples reveal similar patterns, albeit at lower infection rates. For example, recent DHS data show that the prevalence of HIV infection is greater among married fe- 
male adolescents aged 15-19 than among their unmarried sexually active counterparts in countries such as Kenya ( $6.6 \%$ vs. $2.5 \%$ ), Tanzania ( $3.1 \%$ vs. $2.5 \%$ ) and Cameroon (3.9\% vs. $2.0 \%$ ), although these differences are statistically significant only for Kenya.

\section{Sexual Activity and Pregnancy Intentions}

Table 2 examines the relationship between marital status and recent unprotected sex among young women aged 15-19. In all countries except South Africa and Namibia, more than half of adolescent females who had had unprotected sex (i.e., sex without a condom) during the previous week were married; in 18 of the 29 countries, more than $80 \%$ were married. These findings reflect both a lower frequency of sexual activity and greater condom use among unmarried female adolescents than among married female adolescents. If unmarried adolescents are less likely than their married peers to report being sexually active, having sex frequently and having sex without a condom, then our data may overestimate the proportion of unprotected sexual activity that occurs within marriage; nonetheless, these numbers suggest that across tremendously diverse cultural settings, marriage remains the principal relationship context in which adolescent females have sex.

Table 2 also presents the proportions of married, unmarried and sexually active unmarried young women who had had unprotected sex in the previous week. That proportion was strikingly higher among married adolescents than among unmarried ones. Even when the cohort of unmarried respondents is restricted to those who were sexually active, the proportion of adolescents who had had recent unprotected sex was significantly higher among those who were married than among those who were not.

For many adolescent wives, the first year of marriagewhen couples are often trying to conceive their first childmay be the most sexually active period in their entire life. Figure 1 (page 82) shows the frequency of unprotected sex by marital duration among women who married before age 20 in Burkina Faso, Malawi, Mali, Mozambique and Nigerthe five Sub-Saharan countries with the highest proportion of females 18 or younger who are married (data for all 29 countries are available upon request). In many African nations, including most of those in Figure 1, the proportion of adolescent wives who had had unprotected sex during the previous week declined by $10-20$ percentage points between the first year of marriage and the second. Much of this decline may be attributable to these women becoming pregnant with or giving birth to their first child.

Differences in pregnancy desires* may partially explain the differences in the frequency of unprotected sex between married and unmarried adolescents. To investigate this possibility, we examined the proportion of adolescents who had had recent unprotected sex by pregnancy desires and marital status (Table 3, page 83). Although the desire to become pregnant was more common among adolescents who were married than among those who were unmarried but sexually active, it does not fully account for the differ-
TABLE 2. Percentage of female adolescents aged 15-19 who were married, and percentage who reported having had unprotected sex in the previous week, by country, according to sexual activity and marital status

\begin{tabular}{|c|c|c|c|c|c|}
\hline \multirow[t]{2}{*}{ Country } & \multicolumn{2}{|c|}{$\%$ married } & \multicolumn{3}{|c|}{$\%$ who reported unprotected sex } \\
\hline & All & $\begin{array}{l}\text { Had } \\
\text { unpro- } \\
\text { tected sex }\end{array}$ & Married & $\begin{array}{l}\text { All } \\
\text { unmarried } t\end{array}$ & $\begin{array}{l}\text { Unmarried } \\
\text { and sexually } \\
\text { activet }\end{array}$ \\
\hline \multicolumn{6}{|c|}{ South and East Africa } \\
\hline Ethiopia & 24.9 & 97.9 & 73.6 & 0.5 & 25.9 \\
\hline Kenya & 18.4 & 90.5 & 60.7 & 1.4 & 5.2 \\
\hline Malawi & 34.0 & 92.6 & 63.1 & 2.6 & 8.0 \\
\hline Mozambique & 40.2 & 72.5 & 50.2 & 12.8 & 24.2 \\
\hline Namibia & 5.0 & 42.2 & 39.2 & 2.8 & 6.3 \\
\hline Rwanda & 6.6 & 97.2 & 88.5 & 0.2 & 2.6 \\
\hline South Africa & 3.3 & 12.6 & 33.6 & 7.9 & 18.4 \\
\hline Tanzania & 12.4 & 68.0 & 68.6 & 4.6 & 12.5 \\
\hline Uganda & 29.9 & 93.7 & 75.6 & 2.2 & 7.5 \\
\hline Zambia & 24.9 & 81.7 & 54.9 & 4.1 & 9.8 \\
\hline Zimbabwe & 21.9 & 94.7 & 63.9 & 1.0 & 7.9 \\
\hline \multicolumn{6}{|l|}{ West Africa } \\
\hline Benin & 23.4 & 68.1 & 36.2 & 5.2 & 12.4 \\
\hline Burkina Faso & 31.8 & 90.0 & 45.2 & 2.4 & 9.9 \\
\hline Cameroon & 31.6 & 90.1 & 45.8 & 2.3 & 7.1 \\
\hline Côte d'Ivoire & 24.3 & 56.0 & 48.8 & 10.4 & 20.0 \\
\hline Gabon & 18.9 & 53.2 & 48.3 & 9.9 & 16.1 \\
\hline Ghana & 12.2 & 63.6 & 34.3 & 2.7 & 9.2 \\
\hline Guinea & 44.6 & 84.0 & 39.7 & 6.1 & 23.1 \\
\hline Mali & 47.2 & 89.6 & 54.7 & 5.7 & 19.0 \\
\hline Niger & 61.2 & 99.4 & 58.3 & 0.6 & 14.3 \\
\hline Nigeria & 32.3 & 93.4 & 73.2 & 2.5 & 9.2 \\
\hline Togo & 19.3 & 51.6 & 70.6 & 6.9 & 14.2 \\
\hline \multicolumn{6}{|c|}{ Latin America/Caribbean } \\
\hline Brazil & 14.2 & 71.7 & 77.1 & 5.1 & 26.3 \\
\hline Colombia & 14.9 & 77.6 & 75.6 & 3.8 & 14.0 \\
\hline Dom. Republic & 24.1 & 93.5 & 75.2 & 1.3 & 14.9 \\
\hline Guatemala & 24.3 & 100.0 & 55.8 & 0.0 & 0.0 \\
\hline Haiti & 16.6 & 82.6 & 27.8 & 1.2 & 6.3 \\
\hline Nicaragua & 24.3 & 97.3 & 70.8 & 0.6 & 9.8 \\
\hline Peru & 9.9 & 82.9 & 59.5 & 1.4 & 10.4 \\
\hline
\end{tabular}

†Excludes formerly married adolescents. Note: For all 29 countries, the proportion of married respondents who had had unprotected sex in the previous week was significantly greater than the proportion of sexually active unmarried respondents who had done so ( $p<.001$ for all countries except South Africa, for which $p<.01$ ).

ences in frequency of unprotected sex: In nearly every country, married adolescents were significantly more likely than sexually active unmarried adolescents to have had unprotected sex in the previous week, regardless of pregnancy intentions. These differences were generally greater among women who did not wish to become pregnant, particularly in South and East Africa and Latin America, but even among those actively seeking pregnancy in the next two years, married adolescents were, on average, about three times $^{\dagger}$ as likely as unmarried adolescents to have had unprotected sex in the past week (data not shown).

\section{Characteristics of Sexual Partners}

One reason that married adolescents are usually thought to have a lower risk of HIV infection than their unmarried peers is that married adolescents are believed to have fewer sexual partners. Contrary to expectations, however, in most

*Pregnancy desires are determined by women's response to the question, "Would you like to have a child in the next two years?" We note that affirmative responses to this inquiry may reflect women's, men's, or their families' expectations or desires about pregnancy.

†This is a country-level, rather than individual-level, average. 
FIGURE 1. Percentage of married female adolescents aged 15-19 in selected African countries who had had unprotected sex within the past week, by marital duration

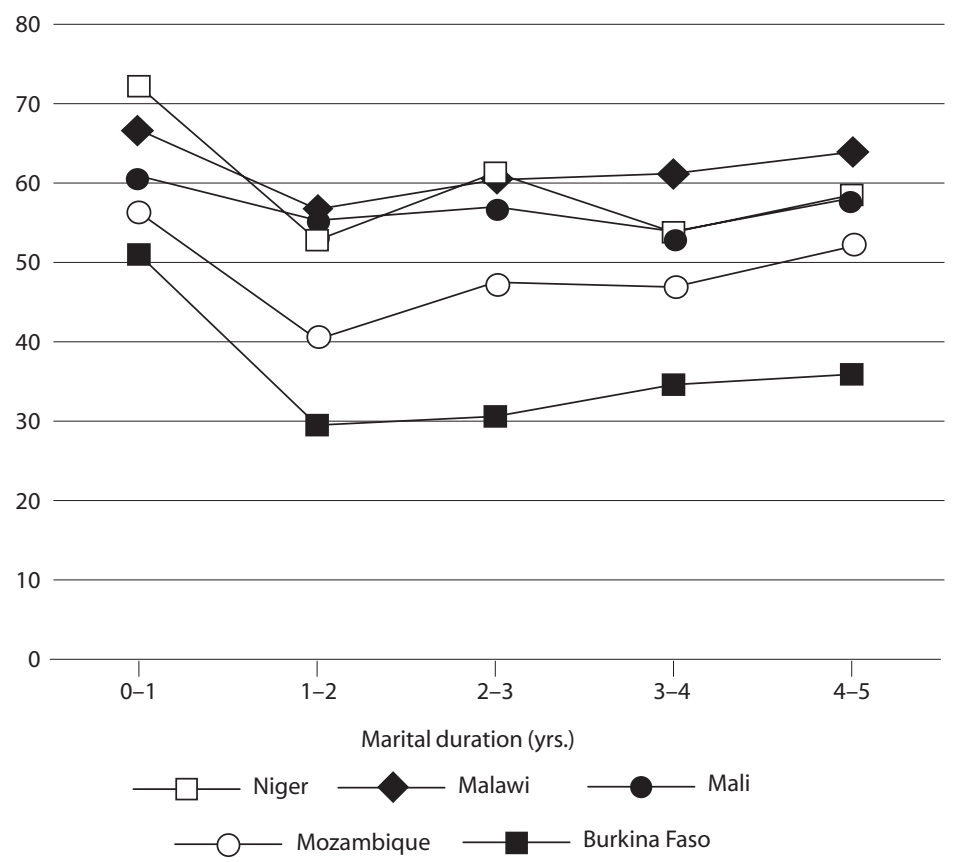

countries the mean number of partners reported by married adolescents exceeded the number reported by sexually experienced unmarried adolescents (Table 4, page 83) There was, however, considerable variation within countries in the number of sexual partners reported by unmarried, sexually experienced adolescents; the majority reported having had one sexual partner in the past year, but up to a quarter were engaging in "secondary abstinence" (i.e., they had refrained from sex for more than a year), and a small but potentially quite important proportion reported having had two or more partners.

This last subgroup of unmarried young women may be at considerable risk, as recent research suggests that having multiple partnerships, particularly concurrent ones, is strongly associated with HIV infection. ${ }^{10}$ In all countries with available data except Kenya and Namibia, unmarried female adolescents were more likely than their married counterparts to report having had two or more sexual partners within the past year; the proportion of unmarried respondents with multiple partners ranged from fewer than 1\% (Kenya) to almost 19\% (Ethiopia).

Despite the lower proportions of married adolescents having multiple partners, several factors call into question the relative "safety" of husbands as opposed to boyfriends. ${ }^{11}$ First, husbands are, on average, older than boyfriends. Second, DHS data indicate that in most countries, the age gap between spouses was larger if the woman married before age 18 (Table 5 , page 84 ). For these women, the average spousal age difference ranged from 4.7 years in Guatemala to 14.2 years in Guinea. The age difference was typically a year or two smaller if the wife was 18 or older when the marriage began.

Polygamy is widely practiced in most of Sub-Saharan Africa: In recent cohorts, $25-43 \%$ of married women aged
20-24 in western Africa and roughly 10-15\% of those in eastern and southern Africa were in polygamous marriages. ${ }^{12}$ The DHS data reveal that in all countries in SubSaharan Africa except Namibia and South Africa (where adolescent marriage is uncommon), women who married before age 18 were more likely than older brides to have polygamous husbands (Table 5); in many of these countries, the difference was substantial.

\section{Restricted Access to Education and Information}

In addition to differing from their unmarried peers with respect to sexual behaviors and partner characteristics, married young women also spend less time in school and have less exposure to the media. As Table 6 (page 85) shows, a woman's age at first marriage is positively related to her total years of schooling; in all 29 countries, women who married when they were 18 or older had more education than those who married at a younger age. The starkest difference was in Nigeria, where women who were at least 18 when they married achieved, on average, 9.3 years of schooling, while those who married before they were 18 remained in school for only 2.5 years. Differences in educational attainment by age at first marriage were evident both in countries with low levels of overall education, such as Burkina Faso, Ethiopia and Mali, and in countries with higher levels of education, such as South Africa, Peru and Zimbabwe.

Although schools are one of the primary venues for HIV education, another route by which messages concerning reproductive health can reach targeted populations is the media; once again, however, women who married at an early age were at a striking disadvantage. In all countries with available data, married adolescents were significantly less likely than unmarried adolescents to watch television; in all but one, they were less likely to read the newspaper weekly (Table 6). Differences with respect to radio exposure were less dramatic but still significant in more than half of the countries.

\section{Lack of Appropriate HIV Prevention Strategies}

Perhaps because of this limited access to information about HIV from educators and the media, married female adolescents were less likely than sexually experienced unmarried female adolescents to know one or more ways of avoiding HIV (Table 7, page 86). Even when compared with all unmarried adolescents, many of whom had not yet had sex, married adolescents were often poorly informed.

Moreover, there appear to be few protective strategies available and accessible to adolescent wives. In all 14 countries for which data are available, married adolescents reported either doing nothing or limiting their sexual activity to one partner (their husband) as their primary strategy for avoiding HIV infection (data not shown). Neither of these strategies offers an effective means of reducing the degree of risk. Although sexually experienced unmarried young women, like their married counterparts, tended to have only one sexual partner, in several countries they reported using condoms or abstaining from intercourse as 
their most common protective strategy. Among all unmarried young women, the most popular protective strategies in the overwhelming majority of countries were either to abstain from sex or to not initiate sexual activity. These options are, for the most part, not available to young women who are married.

The possibility of refusing sexual relations within marriage is virtually eliminated in many instances by the threat of violence. Forty-three percent of married adolescent women in Ethiopia and 64\% of those in Mali stated they felt that husbands are justified in beating their wives if the women withhold sex (results not shown). Coerced sex, particularly coerced first sex, has been linked to poor reproductive health outcomes for young women, including increased risk of HIV infection. ${ }^{13}$

\section{DISCUSSION}

We identified four associations that point to the need for HIV prevention programs that focus on married adolescents. First, marriage coincides with intensified exposure to unprotected sex. For a large fraction of young brides in developing countries, marriage marks the transition from no sexual exposure to regular sexual relations. Even for those who have engaged in premarital sex, marriage may result in a dramatic increase in the frequency of unprotected sexual activity. These changes may be driven in part by the desire for pregnancy.

Second, the husbands of adolescent wives tend to be much older than their spouses. Because of their older age, these men are generally more sexually experienced than the boyfriends of unmarried adolescents; as a result, husbands are, at least in some settings, more likely than boyfriends to be HIV-positive. In one study, for example, the male partners of adolescent wives were more likely than the partners of unmarried adolescents to be infected with HIV in Kisumu, Kenya (30\% vs. 12\%), and Ndola, Zambia (32\% vs. $17 \%) .{ }^{14}$

Nonetheless, it is possible that husbands are less likely than boyfriends to transmit the virus. ${ }^{15}$ This argument rests on findings that viral loads and infectivity rates are quite high in the first few months following infection and then typically decline until symptoms of AIDS appear. ${ }^{16}$ If HIVpositive boyfriends, due to their young age, have been infected more recently than HIV-positive husbands, then one might expect the infectivity of boyfriends to be higher, on average, than that of husbands. No reliable data are available to support or refute this speculation. We note, however, that the prevalence of HIV infection continues to rise for men in many countries until age $35,{ }^{17}$ suggesting that a large number of new infections occur among men in their late 20s and early 30s-an age-group that includes the husbands of many adolescents. Clearly, the relationship between infectivity rates and the age of the male partner warrants additional research.

Another potentially important demographic finding is that the absolute age difference between spouses tends to be larger when women marry before age 18. In general, the
TABLE 3. Percentage of sexually active female adolescents aged 15-19 who had had unprotected sex in the previous week, by country, according to marital status and desire to become pregnant in the next two years

\begin{tabular}{|c|c|c|c|c|}
\hline \multirow[t]{2}{*}{ Country } & \multicolumn{2}{|c|}{ Desires pregnancy } & \multicolumn{2}{|c|}{ Does not desire pregnanc } \\
\hline & Married & Unmarried & Married & Unmarried \\
\hline \multicolumn{5}{|c|}{ South and East Africa } \\
\hline Ethiopia & 88.9 & 73.6 & 67.5 & $22.3^{* * *}$ \\
\hline Kenya & 72.2 & $8.2^{* * *}$ & 56.4 & $5.1^{* * *}$ \\
\hline Malawi & 79.5 & $37.8^{* * *}$ & 57.3 & $6.4^{* * *}$ \\
\hline Mozambique & 69.0 & $43.2^{* * *}$ & 37.3 & $21.7^{* * *}$ \\
\hline Namibia & 55.9 & 33.5 & 35.2 & $4.7^{* * *}$ \\
\hline Rwanda & 81.9 & $0.0^{* * *}$ & 91.1 & $2.8^{* * *}$ \\
\hline South Africa & 70.6 & 43.1 & 26.7 & 18.1 \\
\hline Uganda & 83.5 & $15.2^{* * *}$ & 71.6 & $6.5^{* * *}$ \\
\hline Zambia & 68.4 & $28.3^{* * *}$ & 48.4 & $7.2^{* * *}$ \\
\hline Zimbabwe & 70.5 & $6.6^{* * *}$ & 61.2 & $8.2^{* * *}$ \\
\hline \multicolumn{5}{|l|}{ West Africa } \\
\hline Benin & 62.8 & $17.6^{* * *}$ & 26.8 & $12.1^{* * *}$ \\
\hline Burkina Faso & 70.7 & $7.8^{* * *}$ & 29.9 & $10.0^{* * *}$ \\
\hline Cameroon & 70.6 & $21.5^{* * *}$ & 35.3 & $6.4^{* * *}$ \\
\hline Côte d'Ivoire & 70.8 & $28.2^{* * *}$ & 38.5 & $23.5^{*}$ \\
\hline Gabon & 69.8 & $30.8^{* * *}$ & 42.3 & $15.0^{* * *}$ \\
\hline Ghana & 65.6 & $25.5^{*}$ & 29.5 & $8.7^{* * *}$ \\
\hline Guinea & 58.8 & 40.6 & 25.7 & 22.7 \\
\hline Mali & 67.0 & $25.2^{* * *}$ & 49.4 & $18.5^{* * *}$ \\
\hline Niger & 66.6 & 71.6 & 52.5 & $5.7^{* * *}$ \\
\hline Nigeria & 85.4 & $13.3^{* * *}$ & 60.5 & $9.0^{* * *}$ \\
\hline Togo & 57.9 & $22.2^{* * *}$ & 20.7 & $12.3^{* *}$ \\
\hline \multicolumn{5}{|c|}{ Latin America/Caribbean } \\
\hline Brazil & 71.4 & $36.6^{* *}$ & 77.9 & $25.3^{* * *}$ \\
\hline Colombia & 88.2 & $42.9^{* * *}$ & 74.1 & $14.0^{* * *}$ \\
\hline Dom. Republic & 80.8 & $15.8^{* * *}$ & 75.1 & $17.1^{* * *}$ \\
\hline Guatemala & 67.6 & $0.0^{* * *}$ & 52.0 & $0.0^{* * *}$ \\
\hline Haiti & 36.6 & 30.1 & 27.1 & $5.6^{* * *}$ \\
\hline Nicaragua & 92.4 & $23.5^{* *}$ & 66.7 & $9.5^{* * *}$ \\
\hline Peru & 91.4 & $22.6^{*}$ & 57.5 & $10.0^{* * *}$ \\
\hline
\end{tabular}

${ }^{*} \mathrm{p}<.05 .{ }^{* *} \mathrm{p}<.01 .{ }^{* * *} \mathrm{p}<.001$. Note: $\mathrm{u}=$ unavailable.

TABLE 4. Among sexually experienced female adolescents aged 15-19, mean number of sexual partners in the previous year, and percentage with two or more partners in the previous year, by country, according to marital status

\begin{tabular}{|c|c|c|c|c|}
\hline \multirow[t]{2}{*}{ Country } & \multicolumn{2}{|c|}{ Mean no. of partners } & \multicolumn{2}{|c|}{$\%$ with $\geq 2$ partners } \\
\hline & Married & Unmarried & Married & Unmarried \\
\hline \multicolumn{5}{|c|}{ South and East Africa } \\
\hline Ethiopia & 0.98 & $1.53 \ddagger$ & 1.4 & $18.6^{*}$ \\
\hline Kenya & 1.01 & $0.67^{* * *}$ & 4.3 & 0.8 \\
\hline Malawi & 0.99 & $0.78^{* * *}$ & 1.3 & 2.0 \\
\hline Mozambique & 0.95 & $1.02^{*}$ & 5.8 & $11.2^{* * *}$ \\
\hline Namibia & 1.01 & $0.88^{* * *}$ & 2.9 & 2.8 \\
\hline Rwanda & 1.01 & $0.39 * * *$ & 1.1 & 2.2 \\
\hline South Africa & 1.06 & 1.07 & 5.6 & 7.2 \\
\hline Tanzania & 1.07 & 1.00 & 9.0 & $15.8^{* *}$ \\
\hline Uganda & 1.01 & $0.80^{* * *}$ & 1.7 & $6.1^{* *}$ \\
\hline Zambia & 0.98 & $0.77^{* * *}$ & 1.9 & $6.9^{* * *}$ \\
\hline Zimbabwe & 1.00 & $0.89+$ & 0.7 & $6.8^{*}$ \\
\hline \multicolumn{5}{|l|}{ West Africa } \\
\hline Benin & 0.84 & 0.89 & 0.3 & $4.5^{* * *}$ \\
\hline Burkina Faso & 0.87 & $0.93^{* *}$ & 2.0 & $5.5^{*}$ \\
\hline Cameroon & 0.99 & 0.99 & 6.0 & $14.3^{* * *}$ \\
\hline Ghana & 0.90 & 0.85 & 1.4 & $5.4^{*}$ \\
\hline Guinea & 1.05 & 0.94 & 1.0 & $12.8^{* * *}$ \\
\hline Mali & 0.96 & 0.91 & 1.4 & $6.7^{* *}$ \\
\hline Nigeria & 0.98 & $0.91^{* *}$ & 0.7 & $3.8^{*}$ \\
\hline \multicolumn{5}{|c|}{ Latin America/Caribbean } \\
\hline Brazil & 1.05 & $1.19 * * *$ & 2.9 & $13.1^{* * *}$ \\
\hline Dom. Republic & 1.03 & 1.00 & 2.3 & $8.8^{* *}$ \\
\hline Haiti & 0.98 & $0.79 * * *$ & 1.1 & 2.2 \\
\hline Nicaragua & 1.01 & $0.77^{* * *}$ & 1.1 & 6.4 \\
\hline Peru & 1.02 & $0.70^{* * *}$ & 0.0 & 0.0 \\
\hline
\end{tabular}

${ }^{*} p<.05 .{ }^{* *} p<.01 .{ }^{* * *} p<.001 .+p<.10$. Excludes three outliers: one respondent who reported 80 partners and two who reported 90 . Note: $\mathrm{u}=\mathrm{unavailable.}$ 
TABLE 5. Mean age difference between husbands and wives, and percentage of wives in polygamous marriages, by wife's age at marriage-both according to country

Country

\begin{tabular}{l|l} 
Age difference (yrs.) & $\%$ in polygamous marriage \\
\hline Wife married $\quad$ Wife married & Wife married Wife married
\end{tabular}

South and East Africa

Ethiopia 8.5

Kenya

Malawi

Mozambique

Namibia

Rwanda

South Africa

Tanzania

Uganda

Zambia

Zimbabwe

West Africa‡

Benin

Burkina Faso

Cameroon

Côte d'Ivoire

Gabon

Ghana

Guinea

Mali

Niger

Nigeria

Togo

Latin America/Caribbean§

Brazil

Colombia

Dom. Republic

Guatemala

Haiti

Nicaragua

Peru

8.5
9.1
6.2
6.7
7.2
8.0
7.1
7.9
6.5
6.7
9.1

at age $\geq 18$

at age $<18$

at age $\geq 18$

\begin{tabular}{l|rc|}
$7.5 \dagger$ & 11.5 & $7.1^{*}$ \\
$6.5^{* * *}$ & 20.0 & $10.3^{* * *}$ \\
$4.7^{* * *}$ & 17.1 & $11.3^{* *}$ \\
6.2 & 26.7 & $24.7^{*}$ \\
5.9 & 4.9 & $18.3^{* *}$ \\
$5.5^{* * *}$ & 12.9 & $4.9^{* *}$ \\
$5.3^{* *}$ & 5.2 & 6.1 \\
$6.1^{* * *}$ & 7.6 & $4.5 \dagger$ \\
$5.1^{* * *}$ & 30.7 & $20.8^{* *}$ \\
$5.8^{* *}$ & 15.2 & $11.0 \dagger$ \\
$5.9^{* * *}$ & 20.4 & $11.2^{* *}$
\end{tabular}

${ }^{*} \mathrm{p}<.05 .{ }^{* *} \mathrm{p}<.01 .{ }^{* * *} \mathrm{p}<.001 .+\mathrm{p}<.10$. $\neq$ Among women aged $25-29$ who were married to their first husband. §Among women aged 30-34 who were married to their first husband. Note: $\mathrm{u}=\mathrm{unavailable.}$

evidence linking large spousal age differences and greater power imbalances within marriage is weak and sometimes conflicting. ${ }^{18}$ Nonetheless, a recent National Academy of Science panel on adolescents in developing countries concluded that "there is reason to believe that marriages of young women and older men are less equitable" than other marriages. ${ }^{19}$ If young women married to much older husbands have less power in the relationship, then they may have less ability to negotiate strategies to protect against HIV or to influence their husbands' behavior, whether his use of condoms within the marriage, his engagement in extramarital sex or his use of condoms with nonmarital sexual partners. In addition, in Sub-Saharan Africa, young brides are more likely than older brides to enter into polygamous unions and hence share their sexual risks with their husbands' other wives.

Third, adolescent wives have less access than their unmarried counterparts to social and public sources of information and support. ${ }^{20}$ Our findings suggest that married young women spend less time in school-the primary setting for HIV programs-than do unmarried young women. Similarly, married adolescents are less likely to be exposed to the mass media, another important source of messages designed to help curb the spread of HIV. Eliminating these gaps in access to HIV prevention messages is of vital importance. Moreover, in patrilocal societies, where females leave their natal villages to live with their husbands, adolescent wives' contact with former friends and family members may be severely curtailed. In Amhara, Ethiopia, for example, 15\% of married female adolescents reported having visited with same-sex friends outside the home in the previous week, compared with $24 \%$ of unmarried female adolescents. ${ }^{21}$ This lack of social contact may be important, as emerging research suggests that the advice and experiences of friends and family can have strong, positive effects on the adoption of reliable HIV prevention strategies. ${ }^{22}$

Finally, married young women who are cognizant of HIV risks often rely on remaining faithful to their husbandsand hoping that their husbands remain faithful to themas their only viable protection strategy. Alternative or backup strategies that are used by unmarried adolescents, such as refraining from sexual activity or using condoms, are rarely considered by or even thought feasible for married adolescents. Currently, recommended strategies for protection and risk reduction are to abstain from sexual activity, to reduce the frequency of sexual activity, to change to a safer partner, to use a condom, to know one's own and one's partner's HIV status and to maintain a mutually monogamous relationship with an uninfected partner. Younger brides may be willing and indeed anxious to know their own and their partner's HIV status, but they may face substantial difficulties obtaining their partner's compliance with testing and mutual disclosure of results. In addition, although they may be highly motivated to remain faithful, their ability to influence their husband's sexual behavior might be minimal.

\section{Limitations}

Although many of our analyses show consistent and significant differences between married and sexually active unmarried adolescents, we emphasize that these are associations rather than causal relationships. Being married at a young age is clearly associated with engaging in frequent unprotected sex, having older sexual partners and having less exposure to sources of information, but these results do not prove that getting married causes these differences. One possible interpretation is that adolescents with these characteristics-for example, those with limited educational opportunities-are more likely to choose or be pressured into early marriage. Alternatively, perhaps these associations are driven by both causal and selection effects.

Measurement error, particularly for self-reported data, may also bias our results. For example, whether an adolescent reports herself as being married depends on her interpretation of marriage, which in many cultures is a complex, sometimes fluid arrangement open to considerable ambiguity and variation. Despite our reliance on self-reported data, we found clear differences in sexual behaviors, age of partners, pregnancy intentions, and other social and economic attributes associated with marital status. ${ }^{23}$

Accurate reporting of sexual behavior, especially among 


\begin{tabular}{|c|c|c|c|c|c|c|c|c|}
\hline \multirow[t]{2}{*}{ Country } & \multicolumn{2}{|c|}{ Mean yrs. of schooling $\neq$} & \multicolumn{2}{|c|}{$\begin{array}{l}\% \text { who watch } \\
\text { television weekly§ }\end{array}$} & \multicolumn{2}{|c|}{$\begin{array}{l}\% \text { who read a newspaper } \\
\text { weekly§ }\end{array}$} & \multicolumn{2}{|c|}{$\begin{array}{l}\% \text { who listen to the } \\
\text { radio daily§ }\end{array}$} \\
\hline & $\begin{array}{l}\text { Married at } \\
\text { age }<18\end{array}$ & $\begin{array}{l}\text { Married at } \\
\text { age } \geq 18\end{array}$ & Married & Unmarried & Married & Unmarried & Married & Unmarried \\
\hline \multicolumn{9}{|c|}{ South and East Africa } \\
\hline Ethiopia & 0.7 & $2.5^{* * *}$ & 2.4 & $9.1^{* * *}$ & 0.7 & $4.0^{* * *}$ & 8.0 & $11.7^{*}$ \\
\hline Kenya & 5.7 & $9.0^{* * *}$ & 13.8 & $31.6^{* * *}$ & 10.1 & $26.9^{* * *}$ & 57.7 & 53.5 \\
\hline Malawi & 3.4 & $6.2^{* * *}$ & 1.5 & $6.5^{* * *}$ & 8.6 & $17.9^{* * *}$ & 38.1 & $44.3^{* *}$ \\
\hline Mozambique & 1.8 & $4.0^{* * *}$ & 10.3 & $34.4^{* * *}$ & 1.5 & $9.9^{* * *}$ & 47.1 & $54.3^{* *}$ \\
\hline Namibia & 6.2 & $8.8^{* * *}$ & 13.0 & $33.4^{* * *}$ & 17.0 & $39.8^{* * *}$ & 33.1 & $51.8^{* * *}$ \\
\hline Rwanda & 3.6 & $4.9^{* * *}$ & 4.0 & $8.7^{* *}$ & 2.3 & $6.7^{* * *}$ & 25.0 & 23.7 \\
\hline South Africa & 8.2 & $10.3^{* * *}$ & 51.2 & $66.0^{*}$ & 27.4 & $42.6^{*}$ & 67.0 & 70.8 \\
\hline Tanzania & 4.5 & $6.6^{* * *}$ & 12.2 & $27.8^{* * *}$ & 10.7 & $28.2^{* * *}$ & 34.4 & $42.0^{*}$ \\
\hline Uganda & 3.7 & $6.9^{* * *}$ & 5.4 & $17.8^{* * *}$ & 6.4 & $26.7^{* * *}$ & 30.3 & $40.7^{* * *}$ \\
\hline Zambia & 4.7 & $7.5^{* * *}$ & 14.9 & $33.1^{* * *}$ & 2.9 & $13.8^{* * *}$ & 20.0 & $30.3^{* * *}$ \\
\hline Zimbabwe & 7.3 & $9.7^{* * *}$ & 23.3 & $35.8^{* * *}$ & 19.2 & $36.1^{* * *}$ & 41.5 & 43.2 \\
\hline \multicolumn{9}{|l|}{ West Africa } \\
\hline Benin & 0.8 & $3.0^{* * *}$ & 10.5 & $37.5^{* * *}$ & 1.5 & $9.7^{* * *}$ & 39.8 & $32.0^{*}$ \\
\hline Burkina Faso & 0.6 & $3.5^{* * *}$ & 13.6 & $40.0^{* * *}$ & 1.4 & $10.9^{* * *}$ & 18.3 & $23.8^{* *}$ \\
\hline Cameroon & 4.0 & $8.3^{* * *}$ & 28.6 & $51.9^{* * *}$ & 6.9 & $19.0^{* * *}$ & 22.6 & $30.8^{* * *}$ \\
\hline Côte d'Ivoire & 1.8 & $4.5^{* * *}$ & 53.1 & $80.8^{* * *}$ & 8.8 & $20.1^{* * *}$ & 30.7 & 24.7 \\
\hline Gabon & 6.1 & $7.8^{* * *}$ & 59.8 & $75.4^{* * *}$ & 24.0 & $38.9^{* * *}$ & 67.4 & 62.3 \\
\hline Ghana & 4.6 & $7.6^{* * *}$ & 28.2 & $58.9^{* * *}$ & 2.0 & $22.5^{* * *}$ & 37.7 & 43.4 \\
\hline Guinea & 0.7 & $3.5^{* * *}$ & 17.4 & $46.4^{* * *}$ & 2.0 & $12.9^{* * *}$ & 26.2 & 29.3 \\
\hline Mali & 0.6 & $3.1^{* * *}$ & 30.2 & $57.0^{* * *}$ & 2.5 & $13.3^{* * *}$ & 41.8 & $48.2^{* *}$ \\
\hline Niger & 0.6 & $4.1^{* * *}$ & 22.9 & $45.1^{* * *}$ & 1.6 & $16.2^{* * *}$ & 51.9 & $60.9^{* * *}$ \\
\hline Nigeria & 2.5 & $9.3^{* * *}$ & 18.8 & $51.9^{* * *}$ & 2.2 & $17.3^{* * *}$ & 32.6 & 33.9 \\
\hline Togo & 1.6 & $3.7^{* * *}$ & 30.9 & $62.3^{* * *}$ & 6.2 & $29.3^{* * *}$ & 6.3 & $9.9+$ \\
\hline \multicolumn{9}{|c|}{ Latin America/Caribbean } \\
\hline Brazil & 5.2 & $7.8^{* * *}$ & 81.1 & $92.1^{* * *}$ & 48.7 & $67.1^{* * *}$ & 68.9 & $83.1^{* * *}$ \\
\hline Colombia & 6.1 & $9.8^{* * *}$ & u & u & $\mathrm{u}$ & u & $\mathrm{u}$ & u \\
\hline Dom. Republic & 6.9 & $11.5^{* * *}$ & 87.6 & $95.0^{* * *}$ & 34.4 & $62.2^{* * *}$ & 75.0 & $90.2^{* * *}$ \\
\hline Guatemala & 2.8 & $6.5^{* * *}$ & 47.9 & $71.3^{* * *}$ & 38.0 & $63.0^{* * *}$ & 64.8 & $81.7^{* * *}$ \\
\hline Haiti & 3.6 & $6.3^{* * *}$ & 24.1 & $41.2^{* * *}$ & 24.5 & $43.5^{* * *}$ & 40.3 & $50.1 \dagger$ \\
\hline Nicaragua & 5.0 & $9.0^{* * *}$ & 57.8 & $76.4^{* * *}$ & 36.7 & $51.3^{* * *}$ & 68.6 & $80.4^{* * *}$ \\
\hline Peru & 7.6 & $11.2^{* * *}$ & 47.6 & $66.3^{* *}$ & 28.5 & 25.4 & 70.3 & 75.6 \\
\hline
\end{tabular}

adolescents, is notoriously unreliable. ${ }^{24}$ Reporting errors may vary systematically by whether or not the respondent is married. For example, if unmarried young women are more likely than married ones to underreport their sexual behaviors, then the differences between the two groups will be overestimated. In Cameroon, Kenya and Tanzania, $1-2 \%$ of the unmarried adolescents who claimed never to have had sex were HIV-positive. Although some of these young women may have been infected from sources other than sex, the magnitude of these numbers suggests that some unmarried respondents were reluctant to disclose their sexual activity. Similarly, differences in the number of sexual partners may be underestimated if married adolescents were less likely than unmarried adolescents to disclose multiple partnerships. Comparisons between married and unmarried young women should be interpreted in light of these potential biases.

Finally, both current status and recall data are subject to bias. ${ }^{25}$ Current status measures of adolescents do not take into account that married adolescents tend to be older than unmarried ones, even within the 15-19-year-old agegroup. Recall bias regarding age at first intercourse and age of first marriage in this age-group is probably minimal, however, as both events are likely to have occurred recently.

\section{Policy Implications}

Unmarried young women with multiple partners have received the lion's share of attention in HIV prevention programs and continue to require very specific and targeted strategies. On the other hand, married adolescents-despite facing significant social and behavioral risks-have been marginalized by adolescent HIV/AIDS policies and have not been central in reproductive health programs aimed at adult married women. ${ }^{26}$ Indeed, in many studies, married female adolescents have been portrayed as a low-risk group. Providing effective policy and programmatic interventions for these young women may prove particularly challenging. Yet, overcoming these challenges is important for at least two reasons. First, helping these young wives to avoid becoming infected could serve as a critical firewall, preventing the shift of the HIV epidemic from a concentrated to a generalized one. In developing countries where HIV is currently prevalent only among sex workers and their clients, the wives of these clients are frequently the next group to be infected. Second, although epidemiologic models of HIV transmission rarely identify young married women as important vectors, most of these women are at the beginning of their most intensive childbearing period; thus, protecting them could greatly reduce mother-to-child 


\begin{tabular}{|c|c|c|c|}
\hline Country & Married & $\begin{array}{l}\text { All } \\
\text { unmarried }\end{array}$ & $\begin{array}{l}\text { Unmarried } \\
\text { and sexually } \\
\text { active }\end{array}$ \\
\hline \multicolumn{4}{|c|}{ South and East Africa } \\
\hline Ethiopia & 68.3 & 64.4 & 87.9 \\
\hline Kenya & 78.1 & 80.8 & 85.4 \\
\hline Malawi & 91.3 & 91.5 & 93.9 \\
\hline Mozambique & 59.3 & $71.9^{* * *}$ & 79.1 \\
\hline Namibia & 86.6 & 87.2 & 90.7 \\
\hline Rwanda & 93.6 & 93.0 & 96.6 \\
\hline South Africa & 97.0 & 96.0 & 97.8 \\
\hline Tanzania & 81.2 & 84.0 & 92.6 \\
\hline Uganda & 82.1 & 85.7 & 89.4 \\
\hline Zambia & 78.8 & 78.3 & 80.6 \\
\hline Zimbabwe & 74.4 & $80.8^{*}$ & 82.2 \\
\hline \multicolumn{4}{|l|}{ West Africa } \\
\hline Benin & 26.8 & 22.8 & 82.3 \\
\hline Burkina Faso & 56.7 & $62.8^{*}$ & 78.7 \\
\hline Cameroon & 75.9 & $84.7^{* * *}$ & 89.4 \\
\hline Côte d'Ivoire & 91.5 & 95.6 & 97.5 \\
\hline Gabon & 78.9 & $83.6+$ & 88.0 \\
\hline Ghana & 59.1 & $78.9^{* * *}$ & 81.2 \\
\hline Guinea & 80.5 & 80.9 & 84.8 \\
\hline Mali & 48.6 & $56.6^{* *}$ & 72.4 \\
\hline Niger & 61.6 & 67.2 & 67.2 \\
\hline Nigeria & 57.3 & 59.6 & 64.0 \\
\hline Togo & 61.6 & $74.0^{* * *}$ & 79.7 \\
\hline \multicolumn{4}{|c|}{ Latin America/Caribbean } \\
\hline Brazil & 82.5 & $90.4^{* * *}$ & 94.7 \\
\hline Colombia & 78.4 & $89.5^{* * *}$ & 91.3 \\
\hline Dom. Republic & 90.4 & 91.6 & 95.6 \\
\hline Guatemala & $\mathrm{u}$ & $\mathrm{u}$ & $\mathrm{u}$ \\
\hline Haiti & 50.4 & 53.8 & 68.9 \\
\hline Nicaragua & 33.8 & $40.7^{* *}$ & 36.9 \\
\hline Peru & 70.4 & $83.9^{* *}$ & 78.2 \\
\hline
\end{tabular}

${ }^{*} \mathrm{p}<.05 .{ }^{*} \mathrm{p}<.01 .{ }^{* * *} \mathrm{p}<.001 .+\mathrm{p}<.10$. Notes: Significance testing is for the difference between married adolescents and all unmarried adolescents. Data from Cameroon, Tanzania and Mozambique come from the DHS surveys prior to those listed in Table 1, because the question about avoiding AIDS was not asked in these countries' most recent surveys. u=unavailable.

transmission of HIV as well as dramatically lower the probability of dual-parent orphanhood for their children.

Prescribing specific policy or programmatic interventions is beyond the scope of this paper. Each country (or region within a country) will need to assess the degree and specific sources of HIV risk for young married women. * Our analyses suggest that in nearly every country we examined, including several with mature AIDS epidemics, married adolescents may face higher risks than unmarried adolescents via greater exposure to unprotected intercourse, large age differences with their partners and limited access to information. There are two notable exceptions to this general pattern: South Africa and Namibia. In these two countries, fewer than $50 \%$ of sexually experienced adolescent females are married and levels of polygamy are relatively low. Thus, in these countries, the needs of adolescent wives may not be as great or as pressing as the needs of unmarried, sexually active young women. In contrast, in some countries not included in our study, the risk of HIV infection via early

*Examples of how these data can be applied in three different countries (Burkina Faso, Zambia and the Dominican Republic) are available from the first author marriage may be particularly high. In India, for example, the low level of premarital sexual activity and the high proportion of adolescent females who are married suggest that adolescent sexual activity occurs primarily within marriage. ${ }^{27}$ Married monogamous women are considered to be at low risk. However, one study in urban India found that $14 \%$ of married monogamous women whose only source of risk was their husband were HIV-positive. ${ }^{28}$

In short, specific policy interventions must be tailored to sexual and behavioral profiles of young women in individual countries. The potential effect of increasing young women's age at marriage on HIV risk would depend on how the sexual behaviors of these young women (and their partners) would change. Some policymakers fear that delaying marriage would be accompanied by an increase in sexual activity among unmarried adolescents that would more than offset the decline in sexual activity among married adolescents. However, data from Latin America and Africa show that although the context in which adolescent sexual relationships occur has changed over time (from within marriage to before marriage), the overall percentage of sexually active young women has remained constant, or even declined slightly, as the age of marriage has risen. ${ }^{29}$

In countries where child and adolescent marriage is common and premarital sexual activity among young women is strongly curtailed, delaying marriage by itself might not result in a longer interval between sexual debut and marriage and might actually delay the often involuntary loss of virginity for many young women. Furthermore, in these countries, delaying the age at marriage until at least 18 might afford these women the opportunity to extend their education, develop livelihood skills and strengthen their self-esteem, all of which may help them create healthier and more stable marital unions when they wed.

In other countries, making sexual intercourse within marriage safer may be a more important strategy. The process of getting married can itself be used as an opportunity to reach both brides and grooms with information about HIV/AIDS and to provide HIV testing. Both religious and state institutions could incorporate these elements into the marriage process. Reducing spousal age differences in countries where men marry much younger brides may also help minimize risks associated with marriage, as intergenerational sex is believed to play an important role in perpetuating the HIV epidemic in many countries. ${ }^{30}$ Although the large age differences between unmarried young women and their older, wealthier sexual partners (sometimes referred to as their "sugar daddies" 31 ) have received much media and research attention in parts of Sub-Saharan Africa, in reality the age difference between adolescent wives and their husbands is, on average, much larger than that between unmarried young women and their sexual partners. ${ }^{32}$

Finally, our analyses suggest that the first year of marriage is a period of unusually intense sexual activity for many women. Targeted outreach programs for the recently married have been proposed. ${ }^{33}$ Although the use of condoms within marriage is still relatively unpopular, ${ }^{34}$ it could be 
encouraged as a contraceptive and protective strategy for newly wed couples seeking to delay childbearing. Helping recently married couples solidify their unions and adjust to living together could also help reduce the number of women in one of the highest risk categories, those who have previously been married. ${ }^{35}$

The combination of policies designed to delay marriage until at least age 18 and of policies that recognize and lower HIV risks within marriage could be instrumental in making marriage safer. As with unmarried young women, some subgroups of married adolescents may be at much higher risk than others. Adolescents married to uninfected partners who remain sexually exclusive face minimal risks, whereas those married at young ages to much older men who have or have had multiple partners are acutely vulnerable-especially if these young women are trying to become pregnant. Policymakers have long sought to reduce adolescent HIV risks by discouraging risky premarital and extramarital sexual activity; it is time to also promote concurrent and complementary strategies to reduce adolescent marital sex and foster safer marital sex practices.

\section{REFERENCES}

1. Joint United Nations Programme on HIV/AIDS (UNAIDS)/World Health Organization, AIDS Epidemic Update 2004, Geneva: UNAIDS, 2004.

2. Laga M et al., To stem HIV in Africa, prevent transmission to young women, AIDS, 2001, 15(7):931-934; and UNAIDS, Report on the Global HIV/AIDS Epidemic, Geneva: UNAIDS, 2000.

3. Singh $\mathrm{S}$ and Samara R, Early marriage among women in developing countries, International Family Planning Perspectives, 1996, 22(4): 148-157.

4. Special analysis of DHS data, Population Council, New York, 2005.

5. Singh $S$ et al., Gender differences in the timing of first intercourse: data from 14 countries, International Family Planning Perspectives, 2000, 26(1):21-28.

6. Clark S, Early marriage and HIV risks in Sub-Saharan Africa, Studies in Family Planning, 2004, 35(3):149-160; Glynn J, Buvé A and Caraël M, Decreased fertility among HIV-1-infected women attending antenatal clinics in three African cities, Journal of Acquired Immune Deficiency Syndromes, 2000, 25(4):345-352; and Kelly RJ et al., Age differences in sexual partners and risk of HIV-l infection in rural Uganda, Journal of Acquired Immune Deficiency Syndromes, 2003, 32(4):446-451.

7. Bracher M et al., Assessing the potential of condom use to prevent the spread of HIV: a microsimulation study, Studies in Family Planning, 2004, 35(1):48-64.

8. Curtis SL and Sutherland E, Measuring sexual behavior in the era of HIV/AIDS: the experience of the Demographic and Health Surveys and similar enquiries, Sexually Transmitted Infections, 2004, 80(Suppl. 2):ii22-ii27.

9. Clark S, 2004, op. cit. (see reference 6); Glynn J, Buvé A and Caraël M, 2000, op. cit. (see reference 6); and Kelly RJ et al., 2003, op. cit. (see reference 6).

10. Morris M and Kretzschmar M, A microsimulation study of the effect of concurrent partnerships on the spread of HIV in Uganda, Mathematical Population Studies, 2000, 8(2):109-133; Halperin DT and Epstein H, Concurrent sexual partnerships help to explain Africa's high HIV prevalence: implications for prevention, Lancet, 2004, 364(9428): 4-6; and Morris M and Kretzschmar M, Concurrent partnership and the spread of HIV, AIDS, 1997, 11(5):641-648.

11. Clark S, 2004, op. cit. (see reference 6);

12. Lloyd CB, Growing Up Global: The Changing Transitions to Adulthood in Developing Countries, Washington, DC: National Press, 2005, p. 452.
13. Jejeebhoy $S$ and Bott $S$, Non-consensual sexual experiences of young people: a review of the evidence from developing countries, South $E$ East Asia Regional Working Paper, New Delhi: Population Council, 2003, No. 16; and Koenig M et al., Coerced first intercourse and reproductive health among adolescent women in Rakai, Uganda, International Family Planning Perspectives, 2004, 30(4):156-163.

14. Clark S, 2004, op. cit. (see reference 6).

15. Bongaarts J, Late marriage and the HIV epidemic in Sub-Saharan Africa, unpublished manuscript, Population Council, New York, 2005.

16. Quinn TC et al., Viral load and heterosexual transmission of human immunodeficiency virus type 1, New England Journal of Medicine, 2000, 342(13):921-929; Chakraborty H et al., Viral burden in genital secretions determines male-to-female sexual transmission of HIV-1: a probabilistic empirical model, AIDS, 2001, 15(5):621-627; and Gray RH et al., Probability of HIV-1 transmission per coital act in monogamous, heterosexual, HIV-1 discordant couples in Rakai, Uganda, Lancet, 2001 , 357(9263):1149-1153.

17. Joint United Nations Programme on HIV/AIDS (UNAIDS)/World Health Organization, 2004, op. cit. (see reference 1).

18. Jejeebhoy S, Women's autonomy in rural India: its dimensions, determinants, and the influence of context, in: Presser H and Sen G, eds., Women's Empowerment and Demographic Processes: Moving Beyond Cairo, Oxford, UK: Oxford University Press, 2000; Kishor S, Empowerment of women in Egypt and links to the survival and health of their infants, in: Presser H and Sen G, eds., Women's Empowerment and Demographic Processes: Moving Beyond Cairo, Oxford, UK: Oxford University Press, 2000; Kishor S and Johnson K, Profiling domestic violence: a multi-country study, Calverton, MD, USA: ORC Macro International, 2004.

19. Lloyd CB, 2005, op. cit. (see reference 12).

20. Haberland N, Chong E and Braken H, A world apart: the disadvantage and social isolation of married adolescent girls, New York: Population Council, 2004, pp. 1-12.

21. Erulkar AS et al., The Experience of Adolescence in Rural Amhara Region, Ethiopia, Accra, Ethiopia: Population Council, 2004.

22. Stoneburner RL and Low-Beer D, Population-level HIV declines and behavioral risk avoidance in Uganda, Science, 2004, 304(5671): 714-718

23. Singh $S$ and Samara R, 1996, op. cit. (see reference 3).

24. Curtis SL and Sutherland E, 2004, op. cit. (see reference 8).

25. Zaba B et al., Age at first sex: understanding recent trends in African demographic surveys, Sexually Transmitted Infections, 2004, 80 (Suppl.2):ii28-ii35.

26. Santhya KG and Jejeebhoy SJ, Sexual and reproductive health needs of married adolescent girls, Economic and Political Weekly, 2003 38(41):4370-4377; Erulkar A et al., Adolescent life in low-income and slum areas of Addis Ababa, Ethiopia, Accra, Ghana: Population Council, 2004; and Mekbib T, Erulkar AS and Belete F, Who are the targets of youth programs: results of a capacity building exercise in Ethiopia, Ethiopian Journal of Health and Development, 2005, 19(1):60-62.

27. Santhya KG and Jejeebhoy SJ, 2003, op. cit. (see reference 26).

28. Gangakhedkar RR et al., Spread of HIV infection in married monogamous women in India, Journal of the American Medical Association, 1997 , 278(23):2090-2092; and Newmann S et al., Marriage, monogamy and HIV: a profile of HIV-infected women in south India, International Journal of STD \& AIDS, 2000, 11(4): 250-253.

29. Mensch B, Singh $S$ and Casterline J, Trends in the timing of first marriage among men and women in the developing world, in: Lloyd $\mathrm{CB}$ et al., eds., The Changing Transitions to Adulthood in Developing Countries: Selected Studies, Washington, DC: National Academies Press, 2006; and Zaba B et al., 2004, op. cit. (see reference 25).

30. Gregson S et al., Sexual mixing patterns and sex-differentials in teenage exposure to HIV infection in rural Zimbabwe, Lancet, 2002 359(9321):1896-1903.

31. Kuate-Defo B, Young people's relationships with sugar daddies and sugar mummies: what do we know and what do we need to know? African Journal of Reproductive Health, 2004, 8(2):13-37; and Luke N and Kurz K, Cross-generational and Transactional Sexual Relations in Sub- 
Saharan Africa: Prevalence of Behavior and Implications for Negotiating Safer Sexual Practices, Washington, DC: International Center for Research on Women and Population Services International, 2002.

32. Clark S, 2004, op. cit. (see reference 6).

33. Bruce J and Clark S, The implications of early marriage for HIV/AIDS policy, New York: Population Council, 2004

34. Prata N, Vahidnia F and Fraser A, Gender and relationship differences in condom use among 15-24-year-olds in Angola, International Family Planning Perspectives, 2005, 31(4):192-199.

35. Gray R et al., Marriage and HIV risk: data from Rakai, Uganda, paper presented at the Population Council Workshop on Exploring the Risk of HIV/AIDS Within the Context of Marriage, New York, Nov. 10, 2004

\section{RESUMEN}

Contexto: En la mayoría de los países en desarrollo, la mayor parte de las mujeres adolescentes sexualmente activas están casadas. Si bien con frecuencia se asume que las adolescentes casadas presentan un riesgo muy bajo de infección del VIH, se conoce realmente poco acerca de los riesgos reales que corren estas adolescentes, así como sobre las formas mediante las cuales se podría minimizar estos riesgos.

Métodos: Se usaron los datos correspondientes a las Encuestas Demográficas y de Salud de 29 países del África y América Latina para examinar la frecuencia de los factores que pueden incrementar el riesgo de la infección del VIH entre las mujeres casadas de 15-19 años de edad.

Resultados: Varios factores sociales y de comportamiento pueden incrementar la vulnerabilidad de las mujeres adolescentes casadas ante la infección del VIH. Primero, estas mujeres jóvenes mantienen con frecuencia relaciones sexuales sin protección: en la mayoría de los países, más del $80 \%$ de las adolescentes que recién (en la última semana) habian mantenido relaciones sexuales sin protección estaban casadas. Segundo, las mujeres que se casan temprano tienden a tener cónyuges de mayor edad (una diferencia promedio de edad de 5-14 años) $y$, en las sociedades poligámicas, con frecuencia son las esposas secundarias; ambos son factores que pueden incrementar la probabilidad de que sus maridos sean infectados e igualmente pueden debilitar su poder de negociación en el matrimonio. Tercero, las adolescentes casadas tienen relativamente poco acceso a las fuentes de educación sobre la infección del VIH, incluidos los medios de información. Finalmente, las estrategias de prevención del SIDA más comunes (abstinencia, uso del condón) no son opciones reales para muchas adolescentes casadas.

Conclusión: Para abordar las vulnerabilidades de las cónyuges adolescentes, es necesario elaborar nuevas politicas e intervenciones diseñadas específicamente de acuerdo con los perfiles de las conductas y actitudes sexuales de las mujeres en cada uno de los países. En algunos países, casarse a una edad más avanzada puede ser una importante estrategia; en otros, puede resultar más valioso que las parejas casadas mantengan relaciones sexuales más seguras dentro del matrimonio.

\section{RÉSUMÉ}

Contexte: Dans la plupart des pays en développement, la majorité des adolescentes sexuellement actives sont mariées. Bien que les adolescentes mariées soient souvent considérées comme courant un faible risque d'infection à VIH, les véritables risques et les moyens de les minimiser sont peu documentés.

Méthodes: Les données d'EDS de 29 pays d'Afrique et d'Amérique latine ont servi à l'examen de la fréquence de facteurs susceptibles d'accroître le risque de contraction du VIH couru par les femmes mariées de 15 à 19 ans.

Résultats: Plusieurs facteurs comportementaux et sociaux peuvent accroître la vulnérabilité des adolescentes mariées à l'infection à VIH. Ces jeunes femmes ont tout d'abord souvent des rapports sexuels non protégés. Dans la plupart des pays, plus de $80 \%$ des adolescentes qui avaient eu des rapports non protégés durant la dernière semaine écoulée étaient mariées. Ensuite, les femmes mariées à un jeune âge tendent à avoir des maris beaucoup plus âgés (différence d'âge moyenne de 5 à 14 ans) et, dans les sociétés polygames, elles sont souvent les épouses de rang inférieur, ces facteurs pouvant accroître la probabilité d'infection du mari et affaiblir la capacité de négociation des jeunes femmes au sein du mariage. En troisième lieu, les adolescentes mariées disposent d'un accès relativement faible aux sources éducatives et médiatiques d'information sur le VIH. Enfin, les stratégies de prévention les plus courantes du sida (abstinence et préservatif) n'offrent pas d'options réalistes à de nombreuses adolescentes mariées.

Conclusion: De nouvelles politiques et interventions, adaptées aux profils sexuels et comportementaux des femmes de chaque pays, doivent être définies pour faire face aux vulnérabilités des épouses adolescentes. Dans certains pays, différer l'âge de mariage des filles peut représenter une importante stratégie; dans d'autres, l'encouragement de rapports sexuels à moindres risques au sein du mariage peut être plus utile.

\section{Acknowledgments}

The authors acknowledge the financial support of the World Health Organization, the Bill and Melinda Gates Foundation, the Department for International Development, the Ford Foundation and the MacArthur Foundation. In addition, they thank Population Council staff Nicole Haberland, Sara Rowbottom, Amy Joyce, Rachel Goldberg and Erica Chong for their help in preparing this manuscript.

Author contact: shelley.clark@mcgill.ca 